\title{
PENGARUH NET PROFIT MARGIN (NPM) DAN EARNING PER SHARE (EPS) TERHADAP HARGA SAHAM
}

Furniawan

Sekolah Tinggi Ilmu Ekonomi (STIE) La Tansa Mashiro, Indonesia

Email: furniawan93@gmail.com

\section{Abstrak}

Latar belakang: Dalam Pasar Modal terdapat banyak perusahaan yang memiliki tujuan untuk memperoleh laba dan meningkatkan kemakmuran pemegang saham guna agar perusahaan dapat berkembang dan membawa kemajuan perekonomian Laporan keuangan merupakan faktor penting untuk mentukan mana yang akan dipilh sebagai pilihan investasi bagi para investor

Tujuan penelitian: mengetahui baik secara parsial maupun simultan tentang Net Profit Margin dan Earning per Share terhadap Harga Saham.

Metode penelitian: Metode penelitian kuantitatif dan deskriptif. Jenis data ini skunder tersedia dan dipublikasikan di situs resmi Bursa Efek Indonesia (www.idx.co.id) berupa data pelaporan keuangan perusahaan makanan dan minuman yang terdaftar di Bursa Efek Indonesia.

Hasil penelitian: hasil engujian yaitu memenuhi asumsi-asumsi klasik seperti adanya normalitas data, tidak ada multikolinearitas, tidak ada autokorelasi dan tidak terjadi gejala heteroskedastisitas. Secara parsial NPM tidak Pengaruh sedangkan EPS memiliki pengaruh. Dan secara Bersama-sama memiliki pengaruh signifikan

Kesimpulan: Dalam beberapa kasus, NPM tidak memiliki dampak yang signifikan terhadap harga saham. Dalam beberapa kasus, EPS dapat memiliki dampak yang signifikan terhadap harga saham. Sementara itu, variabel NPM dan EPS memiliki pengaruh yang signifikan terhadap harga saham perusahaan makanan dan minuman yang terdaftar di BEI.

Kata kunci: Net Profit Margin, Earning per Share, dan Harga Saham

\section{Abstract}

Background: In the Capital Market, there are many companies that aim to earn profits and increase the prosperity of shareholders in order for the company to develop and bring economic progress. Financial statements are an important factor in determining which one to choose as an investment choice for investors.

The purpose of the study to know partially or simultaneously about the Net Profit Margin and Earnings per Share on the Stock Price.

Research method: Quantitative and descriptive research methods. This type of secondary data is available and published on the official website of the Indonesia Stock Exchange (www.idx.co.id) in the form of financial reporting data for food and beverage companies listed on the Indonesia Stock Exchange.

The results of the study: the results of the test are that it fulfills the classical assumptions such as the normality of the data, there is no multicollinearity, there is no autocorrelation and there is no symptom of heteroscedasticity. Partially NPM has no influence while EPS has an effect. And Together have a significant influence.

Conclusion: In some cases, NPM does not have a significant impact on stock prices. In some cases, EPS can have a significant impact on stock prices. Meanwhile, the NPM and EPS variables have a significant influence on the stock prices of food and beverage companies listed on the IDX.

Keywords: Net Profit Margin, Earnings per Share, and Stock Price

Diterima: 25-12-2019 Direvisi: 5-01-2021 Disetujui: 6-01-2021

\section{How to cite: \\ E-ISSN:}

Published by: 


\section{PENDAHULUAN}

Pertumbuhan masa globalisasi saat ini, serta ditengah keadaan kehidupan ekonomi serta bisnis yang terus berganti dengan kilat, praktik- praktik ekonomi serta bisnis nyatanya terus menjadi tergantung pada ekonomi serta keyakinan dalam pengalokasian efesiensi di Pasar Modal (Puspitosari, 2012). Kala tembok penghalang arus modal sudah runtuh, hingga pasar jadi lebih terbuka dan mengglobal, dan permintaan serta arus investasi dunia terus bertambah serta mengalir ke penjuru kaswasan yang mempunyai energi tarik investasi semacam pasar modal (Hidayat, 2019). Tidak hanya memandang terdapatnya prospek yang menarik serta menjanjikan untuk investor ataupun calon investor buat menanamkan modalnya di pasar saham bidang indeks, pastinya terdapat perihal lain yang wajib diteliti oleh pemegang investor ataupun calon investor saat sebelum memutuskan buat memananamkan modal di industri tertentu, ialah gimana keadaan sesuatu industri tersebut, spesialnya keadaan keuangan dari industri tersebut (Purwanti, 2018).

Dalam Pasar Modal ada banyak industri yang mempunyai tujuan buat mendapatkan laba serta tingkatkan kemakmuran pemegang saham guna supaya industri bisa tumbuh serta bawa kemajuan perekonomian (Widyaningrum, 2017). Salah satu aspek yang dicermati dalam melaksanakan investasi dipasar modal ialah Harga Saham. Menurut Fahmi, (2017:53) "Saham-saham yang tercantum di sini adalah saham-saham perusahaan lain yang dapat dibeli dan dijual kembali oleh manajemen sewaktu-waktu sesuai kebutuhan". Harga saham yang terus bertambah menggambarkan nilai industri yang baik sehingga hendak mempermudah manajemen dalam memperoleh modal ataupun dana dari pihak luar.

Harga saham senantiasa hadapi fluktuatif tiap detiknya (Sihombing, 2017). Oleh sebab itu, investor wajib mencermati faktor- faktor yang pengaruhi naik turunnya harga saham. Ada sebagian aspek yang pengaruhi harga saham industri baik yang berasal dari aspek fundamental industri ataupun makro ekonomi industri (Triadi \& Suarmanayasa, 2021). Industri yang profit oriented memiliki tujuan utama buat mendapatkan keuntungan semaksimal bisa jadi demi mempertahankan keberlangsungan usahanya (Agung, 2017). Saat sebelum menanamkan modalnya, investor terlebih dulu memandang kinerja industri. Investor pasti cuma hendak menanamkan modal pada industri dengan kinerja yang baik sehingga bisa membagikan keuntungan untuk penanam modal. Pada biasanya, data laba ialah data yang sangat memperoleh atensi dari bermacam golongan paling utama investor (Efendi, 2020).

Selain informasi laba perusahaan, investor juga memperhatikan harga saham perusahaan (Mahastanti, 2011). Untuk mengetahui kesehatan dan kinerja suatu perusahaan dapat dilakukan dengan cara menganalisis laporan keuangan perusahaan yang memerlukan benchmark. Laporan keuangan ialah aspek berarti buat mentukan mana yang hendak dipilh selaku opsi investasi untuk para investor.Tidak hanya itu,laporan keuangan ialah perlengkapan analisis yang sangat gampang serta murah buat didapat para investor.

Fenomena ini dibuktikan dengan realitas kalau di satu sisi, industri wajib bisa menciptakan keuntungan buat bisa menutupi kewajibannya terhadap para pemegang saham serta buat menjauhi melaksanakan pinjaman kepada pihak eksternal demi 
kelangsungan hidup industri. Tetapi perihal ini tidak seluruhnya benar karena pada industri tertentu yang dapat dipercaya, hutang digunakan selaku perlengkapan buat tingkatkan profitabilitas industri sehingga fenomena inilah yang menarik buat diteliti. Bermacam tantangan bisnis tersebut menuntut industri buat mempunyai keahlian respons yang kilat serta fleksibel terhadap tiap kesempatan, ancaman dari luar, tuntutan pelanggan, serta strategi bersaing dengan kompetitor. Berdasarkan uraian latar belakang yang telah disampaikan diatas, penulis tertarik untuk melakukan penelitian dengan tujuan untuk mengetahui baik secara parsial maupun simultan tentang Net Profit Margin dan Earning per Share terhadap Harga Saham.

\section{METODE PENELITIAN}

Metode penelitian kuantitatif dan deskriptif. Menurut Siregar (2015:86) "Pengolahan data Kuantitatif adalah suatu proses dalam memperoleh data ringkas dengan menggunakan ringkasan dengan menggunakan cara-cara tertentu". Tipe informasi dalam riset ini merupakan informasi sekunder yang diterbitkan di web formal Bursa Efek Indonesia ialah www. idx. co. id berbentuk informasi laporan keuangan pada Makanan dan Minuman. Tahun 2019- 2020. Menurut Juliansyah Noor (2014:147) "Populasi digunakan untuk menyebut semua unsur atau anggota daerah yang menjadi subyek atau menjadi subyek penelitian. (Universum) dari objek penelitian". Adapun populasi penelitian ini adalah 30 Perusahaan Makanan dan Minuman yang terdaftar di Bursa Efek Indonesia periode 2019-2020. Menurut Juliansyah Noor (2014:148) "Pengembalian Sampel adalah proses memilih sejumlah elemen secukupnya dari populasi". Tata cara pengambilan sampel dalam riset ini merupakan sampling objektif (Nurdiani, 2014). Maksudnya, metode pengambilan sampel digunakan dengan kriteria bersumber pada informasi yang dijadikan sampel.

Maka sampel yang dijadikan penelitian dengan data lengkap sesuai kebutuhan penelitian adalah sebanyak 18 perusahaan selama 2 tahun dengan data yang diperoleh sebanyak 36 data (Neliana, 2018). Metode pengumpulan informasi yang digunakan dalam riset ini dicoba lewat riset pustaka berbentuk literatur, riset terdahulu dan lewat informasi sekunder, ialah informasi industri yang didapat dari web formal www. idx. co. id yang terdaftar di Bursa efek Indonesia periode 2019- 2020 (Firdhausya, 2019). Variabelvariabel yang diteliti adalah variabel independen yang terdiri dari Net Profit margin dan Earning per Share Variabel dependen yakni Harga saham (Pratama \& Erawati, 2014). Metode Analisis dilakukan menggunakan program SPSS 20 (Lubis \& Andayani, 2017).

Untuk menghasilkan suatu model yang baik maka diperlukan beberapa pengujian yaitu memenuhi asumsi-asumsi klasik seperti adanya normalitas data, tidak ada multikolinearitas, tidak ada autokorelasi dan tidak terjadi heteroskedastisitas (Ardian, 2019) jenis kriteria ketepatan dalam analisa regresi yaitu : uji statistik t, uji statistik F, dan koefien determinasinya $\left(\mathrm{R}^{2}\right)$. Menurut Ghozali (2016 : 97)“Uji statistik t pada dasarnya menunjukkan seberapa jauh pengaruh satu variabel penjelas/independent secara individual dalam menerangkan variasi variabel dependen". Uji t-statistik artinya jika nilai perbedaan signifikan lebih kecil dari 5\% maka terdapat pengaruh yang signifikan secara 
parsial terhadap variabel dependen antara variabel independen dan sebaliknya. Uji $\mathrm{F}$ statistik tingkat signifikansi yang digunakan peneliti adalah 5\%, dan uji $\mathrm{F}$ digunakan untuk membandingkan F-hitung dengan F-tabel. Jika Fhitung > Ftabel, maka Ho ditolak. Sebaliknya. Koefisien determinasi memiliki nilai antara 0 dan 1 . Semakin dekat nilainya dengan nol, semakin kecil pengaruh semua variabel independen terhadap nilai variabel dependen.

\section{HASIL DAN PEMBAHASAN}

Berdasarkan hasil pengolahan data dan hasil temuan yang sudah disusun dalam penelitian ini didapat hasil sebagai berikut:

Tabel 1. Uji Normalitas

One-Sample Kolmogorov-Smirnov Test

\begin{tabular}{llr}
\hline \multicolumn{3}{c}{ One-Sample Kolmogorov-Smirnov Test } \\
\hline & \multicolumn{2}{c}{$\begin{array}{c}\text { Unstandardized } \\
\text { Residual }\end{array}$} \\
\hline $\mathrm{N}$ & \multicolumn{1}{c}{ Mean } & 0E-7 \\
\cline { 2 - 3 } Normal Parameters ${ }^{\mathrm{a}, \mathrm{b}}$ & Std. Deviation & 1987.15164747 \\
\hline \multirow{2}{*}{ Most Extreme Differences } & Absolute & .182 \\
\cline { 2 - 3 } & Positive & .182 \\
\cline { 2 - 3 } & Negative & -.159 \\
\hline Kolmogorov-Smirnov Z & & 1.094 \\
\hline Asymp. Sig. (2-tailed) & & .182 \\
\hline a. Test distribution is Normal. & & \\
\hline b. Calculated from data. & & \\
\hline
\end{tabular}

Berdasarkan Tabel 1. Diperoleh nilai Asymp. Sig. (2-tailed) menunjukkan bahwa secara Bersama-sama Net Profit Margin, Earning per Share dan Harga Saham menunjukkan nilai sebsar 0,182 lebih besar dari taraf kepercayaan $\alpha>0,05$ dapat disimpulkan bahwa semua variabel tersebut terdistribusi normal.

Tabel 2. Uji Multikolinearitas

\begin{tabular}{lllll}
\hline \multicolumn{4}{c}{ Coefficients $^{\mathbf{a}}$} \\
\hline \multirow{2}{*}{ Model } & \multicolumn{3}{c}{ Collinearity Statistics } \\
\cline { 3 - 5 } & \multicolumn{3}{c}{ Tolerance } & \multicolumn{2}{c}{ VIF } \\
\hline \multirow{3}{*}{1} & (Constant) & \multicolumn{3}{c}{1.056} \\
\cline { 2 - 4 } & NPM & .947 & 1.056 \\
\cline { 2 - 4 } & EPS & .947 & \\
\hline
\end{tabular}

a. Dependent Variable: Harga Saham

Berdasarkan tabel 2 diperoleh hasil uji multikolonieritas diperoleh nilai tolerance untuk variabel NPM (X1) sebesar 0,947, EPS sebesar 0,947 Karena semua nilai tolerance lebih besar dari 0,10 dan nilai VIF untuk variabel NPM (X1) sebesar 1,056, EPS sebesar 1,056 karena semua nilai VIF lebih kecil dari 10,00 maka dengan demikian dapat disimpulkan bahwa data-data penelitian terbebas dari masalah multikolonieritas. Sehingga dapat dilanjutkan proses analisis data penelitian. 
Tabel 3. Uji Autokorelasi

\begin{tabular}{lr}
\hline \multicolumn{2}{c}{ Model Summary $^{\mathbf{b}}$} \\
\hline Model & \multicolumn{2}{c}{ Durbin-Watson } \\
\hline 1 & 1.190 \\
\hline
\end{tabular}

Dari tabel 3 diperoleh nilai Durbin-Watson sebesar 1,190 menunjukan bahwa Durbin-Watson yang diperoleh dari hasil pengujian adalah sebesar 1,190 yang berarti berada di rentang $-2<1,190<+2$. Maka tidak ada atau tidak terdapat autokorelasi.

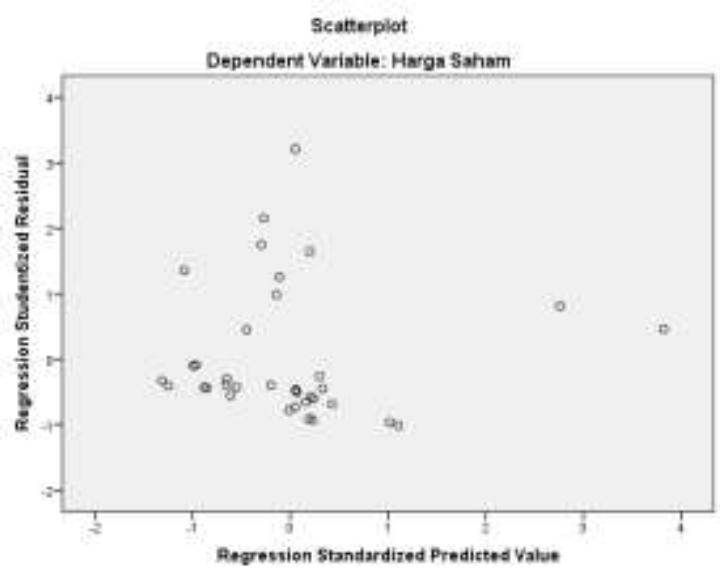

\section{Gambar 1. Uji Heteroskedastisitas}

Berdasarkan gambar 1 terlihat grafik scatterplot terlihat bahwa titik-titik menyebar secara acak serta tersebar baik diatas maupun dibawah angka 0 dan sumbu Y. hal ini dapat disimpulkan bahwa tidak terjadi heteroskedastisitas

Tabel 4. Hasil Uji Regresi Berganda

\begin{tabular}{|c|c|c|c|}
\hline \multicolumn{4}{|c|}{ Coefficients $^{\mathbf{a}}$} \\
\hline \multirow{2}{*}{\multicolumn{2}{|c|}{ Model }} & \multicolumn{2}{|c|}{ Unstandardized Coefficients } \\
\hline & & $\mathrm{B}$ & Std. Error \\
\hline \multirow{3}{*}{1} & (Constant) & -16171.702 & 2028.886 \\
\hline & NPM & .134 & .175 \\
\hline & EPS & 2634.122 & 266.349 \\
\hline
\end{tabular}

Berdasarkan pada tabel 4 terlihat maka dapat disusun persamaan regresinya sebagai berikut: $\mathrm{Y}=\mathrm{a}+\mathrm{b} 1 \mathrm{X} 1+\mathrm{b} 2 \mathrm{X} 2+\mathrm{b} 3 \mathrm{X} 3$

Harga Saham $=-16171,702+0,134$ NPM $+2634,122$ EPS

Dari persamaan regresi tersebut dapat interpretasikan untuk masing-masing variabel sebagai berikut:

a. Nilai konstanta sebesar $-16171,702$ yang dapat diartikan bahwa jika variabel Net Profit Margin dan Earning Per adalah nol maka nilai Harga Saham akan sama dengan nilai konstanta yaitu sebesar $-16171,702$. 
b. Koefisien regresi sebesar 0,134 untuk Net Profit Margin menyatakan bahwa setiap perubahan NPM sebesar 1 satuan, harga saham akan meningkat sebesar 0,134 pada tahun berikutnya.

c. Koefisien regresi sebesar 2634,122 untuk Earning per Share menyatakan bahwa setiap perubahan EPS sebesar 1 satuan harga saham akan Meningkat sebesar 2634,122 pada tahun berikutnya.

Tabel 5. Hasil Uji Korelasi

Model Summary

\begin{tabular}{lll}
\multicolumn{2}{c}{ Model Summary $^{\mathrm{b}}$} & \\
\hline Model & $\mathrm{R}$
\end{tabular}

1

$.867^{\mathrm{a}}$

Berdasarkan hasil tabel 5 disimpulkan bahwa hasil koefisien kolerasi yang ditunjukkan dengan nilai $\mathrm{R}$ adalah sebesar 0,867 . Hal ini mempunyai arti bahwa kolerasi atau hubungan antar variabel bebas yang terdiri dari Net Profit Margin dan Earning per Share terhadap harga saham memiliki hubungan yang sangat Kuat. Sesuai kriteria penilaian kolerasi berganda bahwa 0,867 berada antara koefisien dengan interval $0,800-$ 1,000 yang artinya memiliki hubungan sangat Kuat antara variabel independen terhadap variabel dependen.

Tabel 6. Hasil Uji Determinasi

\begin{tabular}{ll}
\hline \multicolumn{3}{c}{ Model Summary $^{\mathbf{b}}$} \\
\hline Model
\end{tabular}

1 .752

Berdasarkan Tabel 6 diperoleh nilai uji koefisien Determinasi, diperoleh nilai koefisien determinasi (RSquare) sebesar 0,752. hal ini menunjukkan bahwa harga saham (Y) dipengaruhi sebesar 75,2 \% oleh NPM dan EPS, sedangkan sisanya $(100 \%-75,2 \%=$ $24,8 \%$ ) dipengaruhi variabel-variabel lain yang tidak diteliti.

Tabel 7. Hasil Uji T

\begin{tabular}{|c|c|c|c|}
\hline \multicolumn{4}{|c|}{ Coefficients $^{\mathrm{a}}$} \\
\hline Model & & $\mathrm{t}$ & Sig. \\
\hline \multirow{3}{*}{1} & (Constant) & -7.971 & .000 \\
\hline & NPM & .768 & .448 \\
\hline & EPS & 9.890 & .000 \\
\hline
\end{tabular}

a. Pengaruh Net Profit Margin terhadap Harga Saham

Hasil penelitian menunjukkan bahwa NPM memperoleh nilai t hitung sebesar 0,768 dan nilai t tabel sebesar $2.03224(0,768<2.03224)$ dengan nilai signifikan sebesar 0,448 yang mana nilai signifikasi sebesar $0,05(0,448>0,05)$, maka menunjukkan bahwa H1 Ditolak artinya Variabel NPM tidak memiliki pengaruh secara signifikan terhadap harga saham. 
b. Pengaruh Earning per Share terhadap Harga Saham

Hasil penelitian menunjukkan bahwa EPS memperoleh nilai t hitung sebesar 9,890 dan nilai t tabel sebesar $2.03224(9,890<2.03224)$ dengan nilai signifikan sebesar 0,000 yang mana nilai signifikasi sebesar $0,05(0,000<0,05)$, maka menunjukkan bahwa H2 Diterima artinya Variabel EPS memiliki pengaruh secara signifikan terhadap harga saham.

Tabel 8. Hasil Uji F

\begin{tabular}{|c|c|c|c|c|c|c|}
\hline \multicolumn{7}{|c|}{ ANOVA $^{a}$} \\
\hline Model & & $\begin{array}{l}\text { Sum of } \\
\text { Squares }\end{array}$ & df & Mean Square & $\mathrm{F}$ & Sig. \\
\hline \multirow{3}{*}{1} & Regression & $\begin{array}{r}419767929.54 \\
8\end{array}$ & 2 & $\begin{array}{r}209883964.77 \\
4\end{array}$ & 50.114 & $.000^{\mathrm{b}}$ \\
\hline & Residual & $\begin{array}{r}138207008.45 \\
2\end{array}$ & 33 & 4188091.165 & & \\
\hline & Total & $\begin{array}{r}557974938.00 \\
0\end{array}$ & 35 & & & \\
\hline
\end{tabular}

a. Dependent Variable: Harga Saham

b. Predictors: (Constant), EPS, NPM

Berdasarkan tabel 8 diperoleh hasil Fhitung sebesar 50,114 dengan signifikan 0,000 sedangkan $F$ tabel sebesar 3,28. karena nilai $F$ hitung $>F$ tabel $(50,114>3,28)$, maka H3 diterima, dari sini, kita dapat menyimpulkan bahwa NPM dan EPS memiliki pengaruh yang signifikan terhadap harga saham secara simultan.

\section{Pembahasan}

\section{Pengaruh Net Profit Margin (NPM) terhadap Harga Saham}

Dalam hasil penelitian ini menunjukkan bahwa Net Profit Margin tidak memiliki Pengaruh terhadap Harga Saham. NPM tidak mempengaruhi harga saham yang disebabkan oleh NPM itu sendiri, dimana investor lebih memperhatikan penjualan bersih atau penjualan perusahaan saat mengambil keputusan investasi. NPM adalah metrik yang terkait dengan penjualan perusahaan. Hasil penelitian ini sejalan dengan penelitian yang dilakukan oleh Ambarwati, P., Enas, E., \& Lestari, M. N. (2019). Fitriani, S. Z. (2021). menyatakan bahwa Net Profit Margin tidak memiliki Pengaruh terhadap Harga Saham.

\section{Pengaruh Earning Per Share (EPS) terhadap Harga Saham}

Dalam hasil Penelitian ini menunjukan bahwa Earning Per Share memiliki pengaruh signifikan terhadap Harga Saham. Hal ini menunjukkan bahwa EPS telah menentukan tingkat harga saham. EPS biasanya menjadi perhatian bagi pemegang saham umum atau masa depan, karena EPS dapat mewakili jumlah keuntungan yang diperoleh investor untuk setiap saham. Oleh karena itu, peningkatan EPS perusahaan dapat berdampak positif pada harga saham di pasar. Semakin tinggi EPS, semakin tinggi harga saham.Hasil penelitian ini sejalan dengan penelitian yang dilakukan oleh Khoiri, M. F., \& Suwitho, S. (2020), Susanti, M. (2020), Sabrina, S., \& Purbawati, D. 
(2020), Fathurrahman, F., Bahri, S., \& Pawestri, H. P. (2021), Sari, B. M., \& Suriono, H. (2020), Roesminiyati, R., Salim, A., \& Paramita, R. W. D. (2018) dan Sari, I. P., \& Batubara, Z. K. (2020) menyatakan bahwa Earning Per Share memiliki pengaruh signifikan terhadap Harga Saham.

\section{Pengaruh Net Profit Margin dan Earning per Share terhadap Harga Saham}

Dalam hasil penelitian ini menunjukkan bahwa Net Profit Margin dan Earning per Share terhadap Harga Saham memiliki Pengaruh Signifikan secara bersama-sama, Sehingga dapat disimpulkan bahwa secara simultan NPM dan EPS berpengaruh signifikan terhadap harga saham. Hasil penelitian ini sejalan dengan penelitian yang dilakukan oleh Khoiri, M. F., \& Suwitho, S. (2020) dan Furniawan (2021) menyatakan bahwa secara bersama-sama Variabel EPS, ROE dan NPM memiliki Pengaruh Signifikan terhadap Harga Saham.

\section{KESIMPULAN}

Berdasarkan temuan di atas dan pembahasan dapat ditarik kesimpulan sebagai berikut:

1. Dalam beberapa kasus, Net Profit Margin tidak memiliki pengaruh yang signifikan terhadap harga saham.

2. Earning per Share secara parsial berpengaruh signifikan terhadap harga saham

3. Pada saat yang sama, variabel Net Profit Margin dan Earning per Share berpengaruh signifikan terhadap harga saham.

Berdasarkan kesimpulan yang sudah diuraikan, maka peneliti mengemukakan saran untuk Penelitian selanjutnya diharapkan menggunakan variabel bebas selain variabel yang digunakan dalam penelitian ini yang mungkin berpengaruh terhadap harga saham seperti DER, ROA, Size dan lain-lain, diharapkan menggunakan sektor lainnya sebagai objek penelitian.

\section{BIBLIOGRAFI}

Agung, R. R. (2017). PELAKSANAAN PROMOSI DALAM MENINGKATKAN TUJUAN PENJUALAN DISTRO WOODTRAP KAB. BANDUNG.

Ardian, N. (2019). Pengaruh Insentif Berbasis Kinerja, Motivasi Kerja, Dan Kemampuan Kerja Terhadap Prestasi Kerja Pegawai UNPAB. JEpa, 4(2), 119-132.

Efendi, N. (2020). PENGARUH LABA AKUNTANSI DAN LABA FISKAL TERHADAP PERSISTENSI LABA (Studi Empiris Pada Perusahaan Manufaktur yang Terdaftar di BEI Tahun 2015-2019). Universitas Gunung Rinjani.

Firdhausya, A. (2019). Pengaruh hutang terhadap laba usaha pada perusahaan barang konsumsi yang terdaftar di Bursa Efek Indonesia. UIN Sunan Ampel Surabaya.

Hidayat, A. (2019). Wastu Miruda Arsitektur Koprol: Sebuah Kritik Arsitektur. OMAH Library.

Lubis, A. S., \& Andayani, N. R. (2017). Pengaruh kualitas pelayanan (service quality) terhadap kepuasan pelanggan pt. sucofindo batam. Journal of Applied Business Administration, 1(2), 232-243.

Mahastanti, L. A. (2011). Faktor-faktor yang dipertimbangkan investor dalam melakukan investasi. Jurnal Manajemen Teori Dan Terapan, 4(3).

Neliana, T. (2018). Pengungkapan sukarela laporan tahunan dan faktor-faktor yang mempengaruhi. Jurnal Akuntansi Dan Keuangan, 7(1), 79-98. 
Nurdiani, N. (2014). Teknik sampling snowball dalam penelitian lapangan. ComTech: Computer, Mathematics and Engineering Applications, 5(2), 1110-1118.

Pratama, A., \& Erawati, T. (2014). Pengaruh current ratio, debt to equity ratio, return on equity, net profit margin dan earning per share terhadap harga saham (study kasus pada Perusahaan Manufaktur yang terdaftar di Bursa Efek Indonesia periode 20082011). Jurnal Akuntansi, 2(1), 1-10.

Purwanti, L. (2018). Analisis Market Risk Premium, Firm Size, dan Book To Market Equity terhadap Return Saham dengan Menggunakan Model Tiga Factor Fama and French (Studi Pada Perusahaan yang Tergabung dalam Indeks LQ45 Tahun 20132016). Universitas Brawijaya.

Puspitosari, W. A. (2012). Etnis Tionghoa, Tahu dan Kota (Terbangunnya Identitas Kota Kediri).

Sihombing, R. N. (2017). Pengaruh dan Pengungkapan Corporate Social Responsibility terhadap Harga Saham Perusahaan Manufaktur Sektor Industri Barang Konsumsi yang Terdaftar di Bursa Efek Indonesia Periode 2013-2016.

Triadi, I. K. A., \& Suarmanayasa, I. N. (2021). Pengaruh Earning Per Share dan Return On Equity serta Gross Profit Margin terhadap Harga Saham pada Sub Sektor Rokok yang Terdaftar di Bursa Efek Indonesia. Jurnal Ilmiah Akuntansi Dan Humanika, $11(2), 223-231$.

Widyaningrum, N. (2017). Pengaruh Keputusan Investasi, Keputusan Pendanaan, dan Kinerja Keuangan terhadap Nilai Perusahaan dengan Good Corporate Governance sebagai Variabel Moderasi (Studi Empiris pada Perusahaan yang Terdaftar di Bursa Efek Indonesia dan Masuk Peringkat CGPI Periode 2013-2015). Universitas Muhammadiyah Surakarta.

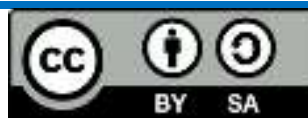

This work is licensed under a Creative Commons Attribution-ShareAlike 4.0 International License 